\title{
Acceptance Issues in the Transition to Renewable Energy: How Law Supposedly can Manage Local Opposition
}

\author{
Birgitte Egelund Olsen
}

Aarhus University

\begin{abstract}
Renewable energy projects are increasingly confronted by persistent resistance from local communities, which delays and sometimes even prevents their implementation. This reflects the frequent gap between support for the general idea of renewables as a strategy for reducing greenhouse gas emissions and acceptance of renewable energy installations in the local landscape. For more than a decade, the Danish Renewable Energy Act has applied various financial measures to promote local acceptance. A general characteristic of the measures is their compensatory purpose, which presupposes that renewable energy facilities have negative impacts. The current toolbox includes instruments aimed at compensating individual house owners for specific financial losses, as well as measures that in more general terms, and ex post, compensate for non-financial impacts. Nevertheless, the toolbox is not yet fully developed and there is a need for further understanding of how different measures work, also in relation to more recently introduced renewables within the local acceptance framework of the Renewable Energy Act, such as solar power. Suggestions are made for the development of more dynamic and flexible regulatory approaches that would include individualized measures tailored to meet the distinct needs of local communities or individual landowners.
\end{abstract}

KEYWORDS: Renewable Energy Act, Local Acceptance, Community Opposition, Renewable Energy, Compensatory Measures

\section{INTRODUCTION}

Recently, Danish legislators have introduced an updated toolbox of financial measures to promote local acceptance of renewable energy projects. ${ }^{1}$ This recent amendment to the Renewable Energy Act adjusts incentives initially introduced with the first Renewable Energy Act in 2008 , and replaces original incentives with new ones. The updated legal toolbox is designed to deal with the well-known concerns of neighbours to renewable energy facilities, such as perceptions of an unfair distribution of burdens and financial benefits, including significant impacts on property prices.

The newly updated toolbox is characterized by even stronger elements of individual compensation. It introduces a 'bonus scheme', which entails direct compensation for households in the proximity of the renewable energy facility. It also imposes an acquisition option - a right for homeowners to transfer ownership of their homes to developers if their property suffers a loss of value due to the renewable energy facility.
However, experience shows that local opposition should be approached with caution, as financial incentives to promote local acceptance can be seen as buying consent or even 'bribery', stirring up further opposition (Olsen, 2016; Jørgensen et al., 2020). As a result, there is a need to rethink the traditional legal approach and revise the current 'damage equals compensation' methodology, and turn to more forward-looking and sustainable regulatory models that may impede an overemphasis on the negative impacts of renewables in the vicinity of where we live.

The current incentives are aimed mainly at onshore facilities and, in some cases, off-shore facilities in coastal areas. As a result, the financial incentives that apply to landbased and near-shore facilities, do not apply to offshore facilities in general, and local communities affected by offshore projects are treated differently. ${ }^{2}$ From a general point of view this may seem logical, as an offshore facility - such as an offshore wind farm - in many cases is not visible from shore. However, this ignores the fact that all large off-shore installations come with large onshore infrastructures. Given that an increased focus on offshore developments is inherent in the next steps towards climate neutrality, there is a need

\footnotetext{
${ }^{1}$ Act No. 738/2020 on amending the Renewable Energy Act.

${ }^{2}$ Completely exempted from the toolbox of financial measures to promote local acceptance are site-specific offshore wind projects subject to tenders.
} 
to consider regulatory models that improve the relationship between offshore project developers and the affected onshore communities.

The overall aim of this paper is to analyse the role of law in addressing community opposition towards renewable energy projects based on Danish experience. More specifically, it examines legal incentives for enhancing local acceptance of renewable energy projects, focusing on measures with a financial element outside the legal framework of planning, site designation, strategic environmental assessment and environmental impact assessment. The analysis has been based on the legal framework, including preparatory works, case law, parliamentary questions etc., applying primarily a legal doctrinal research method. General observations stemming from public debate and insights into specific renewable energy projects also form the basis for the analyses and conclusions. ${ }^{3}$ How the legal framework and the specific regulatory measures actually affect community acceptance falls outside the scope of this paper, as it would require in-depth empirical studies drawing on a broader range of social science methods.

The structure of this paper is as follows: section 2 focuses on community perceptions, local concerns and NIMBYism. Section 3 provides an insight into different categories of financial instruments for promoting local acceptance. In section 4, the current Danish instruments are discussed and suggestions to alter the existing instruments are put forward, although they should not be seen as an exhaustive list nor as fully developed. Focus is on legal measures directly aimed at community opposition issues. Section 5 gives a brief summary and conclusion.

\section{PERCEPTIONS OF RENEWABLE ENERGY AND COMMUNITY OPPOSITION ${ }^{4}$}

Before exploring the different tools for responding to local opposition to the siting of renewable energy infrastructure, it will be helpful to briefly explore the underlying motives and the circumstances under which opposition arises. At a general level, there is strong public support for moving to low carbon energy systems, especially in the main renewable energy-producing countries (Wüstenhagen et al., 2007; Devine-Wright, 2005). However, there is often opposition to renewable energy projects at a local level. Community opposition reflects the frequently large gap between supporting the general idea of renewables as a strategy for mitigating climate change and increasing energy security, and accepting renewable energy installations in the local landscape (Jones and Eiser, 2010; Eltham et al., 2008; Wolsink, 2007).

Community opposition is typically referred to as 'NIMBYism' (Not In My Back Yard). 'NIMBY' refers to a preference for a public good combined with a refusal to contribute to the public good. It also refers to the tension between general and local support for renewables, or simply general resistance to proposed developments (Van der Horst, 2007; Devine-Wright, 2005; Wolsink, 2000). The term is value-laden as it indicates a selfish attitude. However, this more general usage of the term is not an adequate or fair description of people who oppose renewable energy in their local communities. They may not be motivated by self-interest, fear of development or inability to understand the importance of combatting climate change. The term does not adequately account for other explanations for opposing renewable energy projects, such as broader concerns of distributive fairness and lack of transparency or inclusiveness in the decisionmaking processes (Nolon, 2011; Wolsink, 2012; Jørgensen, 2019).

There are many reasons why local communities may object to renewable energy developments. There are at least the following categories of factors: physical, health, environmental and financial factors, perceived distributional fairness and level of inclusion in the decision-making procedure.

The physical or technical factors include the visual impacts and the aesthetic intrusion of renewable energy facilities. Moreover, local opposition may concern noise, flickering shadows or simply the proximity of installations. In Denmark, issues such as visual impacts and noise from wind turbines are dealt with by public law requirements, such as requirements for minimum distances and noise thresholds. There are not (yet) such specific requirements with regard to solar parks etc. Nonetheless, local opposition prevails even if intensive public law regulation of adverse effects applies.

Health concerns are closely related to physical factors. Uncertainty about the health im-pacts of a renewable energy facility may be an important contributor to local opposition (Horner et al., 2011). Another frequent concern is the impact on the environment, including on wildlife, for example bats and birds, the ecosystem in general, and the impact on vegetation and groundwater connected with building access roads and hard-stand areas.

Moving renewable energy production offshore, away from the coast, may reduce or even eliminate visual and immediate health impacts from the renewable energy facility as such. However, it does not per se erase community opposition. Offshore projects are not necessarily 'out of sight, out of mind', but may remain contested. The onshore infrastructure for offshore wind farms is in many cases disputed, such as cable connections and the construction of transformer stations. ${ }^{5}$

Another important concern is the financial impact of renewable energy installations on members of the affected community. People are generally concerned about the effect of solar parks and wind farms on their surroundings and on the value of their property. Community opposition may also be due to the financial effect on conflicting land uses, such as a large solar park near a recreational area or an offshore wind farm disrupting the view of the sea from holiday rentals.

Beyond more direct impacts, another critical issue is the symbolic and affective aspects of renewable energy development, including perceptions of distributional inequity, for instance whether there is a fair sharing of the costs and benefits of projects (Wüstenha-gen et al., 2007; Devine-

\footnotetext{
3 From 2009 until 2019, the author was Chairman of the Valuation Authority of Region Midtjylland. Currently, the author is member of the Energy Board of Appeal (2009-) and Chairman of the Environment and Food Board of Appeal (2017-).

4 This section constitutes an updated version of section I.39.2 in Olsen (2016) 477-479.

5 This has proved to be problematic in a number of offshore projects, for example in the Energy Board of Appeal cases relating to the Anholt Wind Farm, cf. Decision File No. 1011-12-3185, 30 August 2012.
} 
Wright, 2005). Moreover, when a development benefits some sections of a community at the perceived expense of others, this may damage relationships and divide communities, leading to increased opposition.

Finally, resistance to renewable energy projects may not be directed at the infrastructure, affiliated infrastructure or the negative impacts it causes, but may be due to mistrust of the developer, the decision-making process or the public authorities that approve the development plans. Citizens' attitudes towards development will largely depend upon the perceived possibility of influencing the decision-making (Wüstenhagen et al., 2007). Citizens who doubt the credibility of the information they receive or their ability to influence decision-making will be less likely to exercise their rights to participate in consultations and to support a project proposal.

Local authorities, which are often very sensitive to organized local opposition, have to balance the negative local impacts of renewable energy projects against the wider national or global benefits. This is even more of a challenge if the legal framework does not provide for an adequate balancing of these sometimes conflicting interests. Nevertheless, local authorities and developers cannot avoid addressing potential conflicts with local interests. A failure to address issues of local acceptance increases the risk of projects being delayed or simply failing.

\section{ADDRESSING LOCAL ACCEPTANCE THROUGH LAW - THE DANISH TOOLBOX}

The legal framework for replacing carbon-dependent energy systems with renewables must provide well-thought-out incentives for enhancing local acceptance of renewables, while at the same time acknowledging that no two cases are the same and not all opposition can be eliminated. Danish legislators have been at the forefront with regard to the adaptation of law-based incentives directly aimed at promoting community acceptance. However, the instruments applied focus strongly on the negative financial impacts of renewable energy projects and the approach is entirely compensatory.

The first legally binding measures directly addressing community opposition were introduced with the first Renewable Energy Act adopted in 2008. It enacted an individual compensation scheme, which applied to all types of property, including existing wind turbines that would be subject to wind shadows from a future wind project (Mortensen, 2011). The 2008 Act also introduced a co-ownership scheme, which imposed an obligation on developers to offer a minimum of 20 per cent ownership of wind projects to local citizens. It was supposed to promote a feeling of local control and a sense of 'ownership' of the project. The 2008 Act also introduced a community benefit scheme, which provided funding for projects that enhanced local scenic and recreational values. This was a one-off payment based on the capacity of the project and funded by electricity consumers as part of general energy taxation, contrary to the other measures that were financed by wind developers.

Since the 2008 Renewable Energy Act, the measures for improving local acceptance have been amended a number of times, especially their scope of application, and in some cases they have even been replaced by new initiatives. Accordingly, the diversity of the toolbox has decreased with the latest amendments to the Renewable Energy Act, and today individual compensatory measures are by far the leading approach.
Most noteworthy in terms of community involvement is the abandoning of the idea of co-ownership (Olsen, 2014, 2016; Johansen and Emborg, 2018; Jørgensen, 2019).

\subsection{INDIVIDUAL COMPENSATORY MEASURES}

Often the development of renewable energy facilities raises the concerns of neighbours about the impact on their property value. In response to this, individual compensatory measures have been introduced. More generally, the reasoning is that a fairer distribution of benefits and losses will generate more general acceptance of renewable energy projects in local communities. However, there is a fine line between compensation and 'bribery'.

The 2020 Renewable Energy Act contains three partly interlinked legal measures that aim at compensating individual losses, thus challenging the perception that the underlying aim is to bribe local individuals by offering financial benefit schemes. The compensatory instruments are: the compensation scheme, the acquisition option and the renewable energy bonus scheme.

\subsubsection{THE COMPENSATION SCHEME}

The compensation scheme within the frameworks of the Renewable Energy Act functions as an individualized compensatory payment based on tort law principles, compensating specific losses of property value (Jørgensen et al., 2020). The scheme, which was introduced with the first Renewable Energy Act in 2008, aims at gaining acceptance of new renewable energy projects from owners of affected dwellings close to the site. The reasoning is that the neighbours to a wind turbine, for instance, would be more willing to accept it if they were compensated for the loss of value of their property. It entails a requirement for the developer to pay compensation for the loss of property value to dwellings caused by the installation of renewable energy facilities. This includes not only wind turbines, but also solar parks (since 2018), and most recently, wave and hydro power plants, and hybrids of all the above energy facilities. The scheme requires renewable energy developers to fully compensate neighbours for their loss of property value, if they are facing more than a 1 per cent decrease in property value and have not contributed to the loss.

The level of compensation may be settled either by a private agreement between the developer and the neighbour or by an administrative decision of the Valuation Authority, set up specifically to deal with neighbours' claims for compensation. In practice, decisions are made by the Valuation Authority. Under the scheme, neighbours are required to submit a claim for compensation to be eligible for compensation. It costs nothing for a neighbour to submit such a claim if the dwelling in question is in close vicinity to the renewable energy facility. If this is not the case, the applicant must pay an administration fee of EUR 530. However, the fee is reimbursed if compensation is granted.

With the latest amendments to the Renewable Energy Act, the time of the assessment carried out by the Valuation Authority has been pushed forward. It now takes place when the production of power has begun. Previously, decisions on the level of compensation were based on visualisations of the future renewable energy facility. The reasoning behind this was to make sure that the developer would know all the costs related 
to the compensation scheme early in the process. A neighbour would also know the economic consequences of living next to a renewable energy facility relatively early, and would in theory not be tied down to a house during the planning process. However, experience has shown that preparing visualizations is economically relatively burdensome, and neighbours often distrust the correctness of the visualization and hence the decision made by the Valuation Authority, which in some cases has led to legal proceedings. ${ }^{6}$

Consequently, by changing the time of assessment, decisions will in future be based on the actual impacts of the renewable energy facility, and fewer decisions will, in theory, be reopened and taken to court (Energy Agency, 2019a). The main criteria for calculating loss of property value have not changed with the latest amendment. Based on a brief site visit to each dwelling, the Valuation Authority takes into consideration the characteristics of the area, visual interference, distance to the renewable energy installation, estimated levels of disturbance, including noise and reflections, public and private restrictions on the property, the property value and type of dwelling, and the housing market conditions.

Since 2009, about 1300 decisions have been made by the Valuation Authority covering approximately 130 different projects (Energy Agency, 2019a). So far, the majority of decisions concern land-based wind energy. The only other renewable energy projects completed under the compensation scheme have been two solar parks, both from 2020.7 At present, two near-shore wind projects are pending (Anker and Olsen, 2019). They have resulted in about 600 claims for compensation, thus proving that the perceived impact of offshore installations is not comparable to projects on land (Energy Agency, 2019a). Furthermore, this first experience with near-shore wind projects has revealed a weakness in the system, as the functionality of the compensation scheme has been put under a huge pressure, almost undermining the system in practice.

Looking at the period from the enactment of the Renewable Energy Act in 2009 to November 2019, applicants have been granted compensation in about 68 per cent of the decisions made by the Valuation Authority. The average compensation in proportion to the property value of the dwelling is 8 per cent. This corresponds to an average compensation of about EUR 15,500, although compensation of between EUR 3,350 and 13,350 has been granted in about two thirds of the cases (Energy Agency, 2019a).

As mentioned above, two solar park projects have been assessed under the scheme. They generally do not deviate significantly from the level of compensation granted for land-based wind projects. The average compensation in proportion to the property value of the dwelling for the first two solar projects under the scheme is only slightly lower, at around 6.7 per cent. This corresponds to an average compensation of about EUR 7,750.

The Danish compensation scheme takes the view that wind turbines, solar parks and other renewable energy installations will cause a loss in value to neighbouring properties. However, do they in fact inflict an economic loss? And if so, then to what extent?
Only relatively few studies of individual compensating measures have been carried out, and the results are not concordant. So far, the studies concern wind energy. There are no applicable studies of the impact of solar parks. While some studies clearly anticipate negative effects on property values (Jensen et al., 2014; Cowi, 2016; Sunak and Madlener, 2016), others have demonstrated that wind turbines may not have a measureable impact on house prices, or the impact may be relatively low and not necessarily permanent (Hoen et al., 2013; Vyn and McCullough, 2014; Dröes and Koster, 2016; Vyn, 2018).

The most recent Danish study shows that the average level of compensation of the Valuation Authority is only slightly higher than what the study models imply (Jensen et al., 2018). Concerning the impact of near-costal wind farms on property values, the same study interestingly shows that there is no significant effect on property prices (Cowi, 2016). Nevertheless, Danish lawmakers assume that this is the case by including near-shore projects among the renewable energy projects that are subject to the compensation scheme.

Offshore wind projects will presumably also affect property prices in practice, although the Valuation Authority has not yet released any final decisions on the matter. Since some level of discretion is involved in assessing losses in property value, it is simply presumed that the Valuation Authority will be influenced by the fact that the legislation assumes there will be an effect on property prices.

\subsubsection{THE ACQUISITION OPTION}

The acquisition option is a new instrument within the framework of the Renewable Energy Act. The measure responds to the concerns of neighbours of not being able to sell or live in their homes (Energy Agency, 2019b). However, it is not an entirely new legal instrument, either in law or in practice.

A similar measure is incorporated into the Act on Wind Turbine Testing Sites at Høvsøre and Østerild. ${ }^{8}$ According to the Act, any homeowner within a certain distance of the nearest testing turbine may request that the state takes ownership of their property at a price that corresponds to the official property valuation. ${ }^{9}$ So far, only one homeowner has made use of the instrument. A similar instrument has also been used by developers on a voluntary basis to reduce local opposition from neighbours, and in some cases also to enable compliance with distance and noise standards for wind turbines. Apparently, the price determination has been a little higher in these cases, roughly corresponding to the official property valuation plus 20 per cent (Energy Agency, 2019b).

The new instrument is closely connected to the compensation scheme by law. However, the scope of the acquisition option is much narrower, as it only covers the neighbours living closest to the renewable energy facility,

\footnotetext{
${ }^{6}$ Numerous cases have been reviewed by the courts, however, only two cases have been granted leave to appeal to a third instance, and have thus been reviewed by the Supreme Court, cf. UfR 2017.3354, Ejstrup Case and UfR 2018.3205, Nørhede-Hjortmose Case.

7 Solar Park Næssundvej and Solar Park Harre.

8 Act. No. 1069/2018 (Act on Testing Sites).

9 At the Østerild Testing Site, it was within a distance of 1,500 m, while at Høvøøre Testing Site, it was within a distance of $900 \mathrm{~m}$.
} 
while the compensation scheme covers any loss of property value constituting more than 1 per cent, irrespective of the distance. ${ }^{10}$

The acquisition option constitutes a right for an individual homeowner to transfer ownership of property to a renewable energy developer if the property suffers a loss of value due to the renewable energy facility. The renewable energy developer is obliged to buy the dwelling at a price set by the Valuation Authority. However, the obligation only applies when the dwelling is at least partly located within a distance equal to six times the height of the closest wind turbine, or $200 \mathrm{~m}$ from a solar park, hydro power plant etc., and provided that the homeowner has been granted a compensation payment under the compensation scheme. The homeowner may notify the developer within a certain time span that he or she wants to utilise the acquisition option - and thus trigger the legal obligation of the developer to buy the property. ${ }^{11}$

The introduction of the acquisition option entails that the Valuation Authority is obliged to not only assess the loss of property value, but also to asses and determine the price if the acquisition option is activated. The option, and hence the price determination, only covers the dwelling and the close surrounding areas. However, neither the Renewable Energy Act nor the preparatory works provide any guidance as to how the price should be determined, and whether it should be a price estimate (as under the compensation scheme), or a more careful and exhaustive price setting.

\subsubsection{THE BONUS SCHEME}

Like the acquisition option, the renewable energy bonus scheme is also a new instrument within the framework of the Renewable Energy Act. The reasoning behind the bonus scheme is to offset perceptions of unfair distribution of the financial benefits from a renewable energy project between the developer and the local households that are affected by the perceived burdens from the project. ${ }^{12}$ Lawmakers also expect the instrument to contribute to enhanced local support and involvement in the project, including a sense of local ownership. ${ }^{13}$

Unlike the acquisition option, the bonus scheme has not yet been used to promote renewable energies. Nevertheless, for a number of years it has formed part of the legal toolbox for promoting the Copenhagen Metro Line, providing the legal basis for compensating neighbours for significant noise impacts during evenings and nights during the construction period. ${ }^{14}$
The bonus scheme directly compensates a household living in an existing dwelling in the proximity of the renewable energy facility. ${ }^{15}$ A household is one or more physical adult persons, registered as living at a specific address in the social security register. Unlike the compensation scheme and the acquisition option, this instrument is directed towards the household of a dwelling, not the owner. To avoid social imbalance, the bonus is tax-free, and it is not set off against any social benefits. Moreover, the compensation does not counterbalance a specific loss, such as a loss of value. Instead, it is a general and uniform sum that does not reflect any differences in the impact.

The households eligible for a renewable energy bonus are only those living the closest to the facility in question. In relation to solar parks, hydro plants etc. the bonus scheme covers the same dwellings as those that may file a claim for compensation without paying a fee, and those covered by the acquisition option. Concerning wind, the scope of application is wider as the scheme covers households living in dwellings located within a distance of eight times the total height of the nearest turbine, while the limiting distance under the other acceptance schemes is six times the total height of the nearest turbine. ${ }^{16}$

The bonus is not automatically payable to the eligible households. To receive the bonus, the household has to formally accept the offer from the developer. Confirmation is subject to certain conditions. The acceptance has to be provided in writing, determine the allocation of the bonus among the members of the household and be submitted within an eightweek-deadline. It is essential that the household meets the deadline, as there is no legal basis for any extenuating circumstances, unlike the eightweek-deadline for submitting a claim under the compensation scheme. ${ }^{17}$

The developer is obliged by law to pay the bonus and to implement the scheme, while the Energy Agency monitors the individual projects and ensures that the bonuses have been calculated correctly. The bonus calculation is based on the capacity of the renewable energy facility, the production above $5 \mathrm{~kW}$ and the electricity price. According to the preparatory works, the average bonus per household is expected to be around EUR 670 per year in relation to wind projects, and EUR 270 for solar parks etc. ${ }^{18}$ However, this will depend largely upon the availability of resources (such as wind and sunlight), as well as electricity prices and the efficiency of the facility. Furthermore, to limit the economic burden on the developer, the law sets a cap on the amount payable under the bonus scheme. ${ }^{19}$

\footnotetext{
${ }^{10}$ Dwellings located more than $5 \mathrm{~km}$ from the nearest turbine have been grated compensation under the scheme, cf. Bill No. L 114, Folketingstidende $2019-20$, Appendix A, 18.

11 The time span is a maximum of one year and at least three months. The minimum time span for farmhouses is six months, cf. Renewable Energy Act, s 6(5).

12 Bill No. L 114, Folketingstidende 2019-20, Appendix A, 19.

13 Answer to Section 20 Question No. S 1152 (Parliamentary Question to the re-sponsible Minister) File No. 2020-1396, 18 May 2020; Energy Agency (2019c).

${ }^{14}$ Act No. 552/2007 on the Copenhagen Metro as amended by Act No. 748/2014, s 14 b(1), cf. s 14b(5), and as implemented by Executive Order No. $768 / 2014$.

15 The Act is implemented further by Executive Order No. 745/2020 on Renewable Energy Bonus to Neighbours to Wind Turbines, Solar Parks, Wave- and Hydropower Plants.

16 The preparatory works do not elaborate on the reasoning behind this variation.

17 The preparatory works do not touch upon this difference.

18 Bill No. L 114, Folketingstidende 2019-20, Appendix A, 18.

19 The cap is 1.5 per cent of the capacity of the project in question.
} 


\subsection{COMMUNITY-AIMED COMPENSATION}

As a supplement to the individual compensatory instruments, a community-aimed compensation scheme - the green fund - has been introduced to encourage acceptance of renewable energy facilities not only from the primary affected neighbours, but also the surrounding community. The green fund also aims to enhance and promote local government support for the green energy transition locally.

The green fund is not an entirely new legal instrument. It bears some resemblance to the previous green scheme, which formed part of the first Renewable Energy Act. The green scheme provided funding for community projects, which either enhanced the local landscape and recreational values or initiated cultural and informative activities in local associations in the municipalities. It was managed by the Energy Agency. Initially, the previous scheme was financed by electricity consumers as part of general energy taxation. However, since 2017 it formed part of the national Budget. ${ }^{20}$ The green scheme is no longer active.

Unlike the green scheme, the new initiative is managed locally by the municipality hosting the renewable energy facility. ${ }^{21}$ Under the green fund, the developer pays a fixed amount per MW installed, inter alia, EUR 16,700 for land-based wind, EUR 22,000 for offshore coastal or open door wind and EUR 5,400 for solar. The amount is payable almost immediately after the production of the first $\mathrm{kWh}$.

The green fund offers a stronger financial incentive to the hosting municipality. Firstly, a small percentage of the payment is set aside for administration of the fund. Secondly, there are few constraints on the type of projects that may be funded. Finally, the hosting municipality is left with discretionary powers as to how to prioritize the applications for funding, including whether to give priority to projects that benefit the areas or citizens affected by the renewable energy facility in question. The scope for funding projects is thus wider than under the previous centralized regime of the green scheme, which provided funding for projects such as the renovation of sporting facilities, installation of solar power, enhancement of local art, cycle paths, nature trails and recreational areas etc. (Olsen and Anker, 2014).

The previous green scheme was popular among municipalities. ${ }^{22}$ In addition, it was not disliked by developers and after its expiry, some developers continued the payment on a voluntary basis (Energy Agency, $2019 \mathrm{~d})$. The green fund provides even more room to manoeuvre for local governments, and is expected to be warmly welcomed. It is thus the expectation of the lawmakers that this instrument will contribute to the adoption of more (legally) binding land use plans for the development of renewable energies.

\section{RETHINKING THE DESIGN OF LEGAL INSTRUMENTS}

A strategy for dealing with community opposition must be cautious. The types of financial measures that enhance local acceptance may vary in different regions or under different circumstances. The same method for increasing local acceptance may not work everywhere and in all projects. In addition, financial measures to promote local acceptance are often perceived as attempts to buy consent or as 'bribery', thus stirring up further opposition. Moreover, legal measures that entail complex procedures are often less transparent.

Accordingly, there is a need to rethink the traditional legal approach and revise the current 'damage equals compensation' methodology and turn to more forward-looking and sustainable regulatory designs that may reduce the current overemphasis on the negative impacts of renewable energy facilities and the lack of transparency. In general, the current instruments stipulated in the Renewable Energy Act have a predominatelynegative outlook. For instance, the compensation scheme is highly focused on the negative impacts of renewable energy projects, suggesting that wind turbines and solar parks automatically cause a loss of property value. Similarly, the acquisition option implies that renewable energy facilities not only cause a loss of value to property. It implies that it is somehow not possible to live in a house located in the vicinity of, for example, a wind turbine, even if it is further away from the nearest turbine than legally required. The abovementioned instruments also lack transparency.

\subsection{SUGGESTIONS AND REMARKS CONCERNING EXISTING LEGAL MEASURES}

The compensation scheme, which was introduced as a final demand stipulated by the Danish People's Party, ${ }^{23}$ has from the outset been highly controversial, but for different reasons (Olsen, 2010, 2015; Jørgensen, 2019; Jørgensen et al., 2020). While the costs of the scheme may not be as high as predicted by the wind developers back in 2008, the scheme is still questionable from a local acceptance point of view.

First, renewable energy facilities are treated differently from a number of large or intrusive infrastructure projects of vital public interest, such as highways, biogas installations and landfill sites. Such installations only give rise to compensation if the activity results in an unreasonable interference that exceeds the 'tolerance limit' under disturbance legislation (Olsen and Anker, 2014). This in itself seems to indicate that renewable energy facilities cause great impacts even if public law requirements (such as distance and noise standards) are adhered to. The scheme thus emphasises the negative local impacts of renewable energy projects, while the overall societal benefits of energy from renewable sources generate less attention.

\footnotetext{
20 The amendment was a result of the expiry of the EU Commission's state aid approval (case N 354/2008).

21 Executive Order No. 742/2020.

22 Amounts corresponding to 97 per cent of the total funding have been used under the previous green scheme involving 47 municipalities.

23 Det energipolitiske udvalg (2008) L 55, Betænkning over Forslag til lov om fremme af vedvarende energi, Folketinget 2008-09, 2.
} 
Second, there is an obvious gap between the intentions and the actual performance of the compensation scheme. This is in particular due to the challenges of ensuring a fair and acceptable level of compensation that reflects a fair distribution of the burdens and benefits of a renewable energy project, and which is acceptable to the affected homeowners (Jørgensen, 2019). A recent study found that the compensation scheme often undermines the positive effects of the project on local acceptance, and may even be counterproductive. The study shows that while the compensatory instrument is recognised as fair, the compensation as such is perceived as insufficient to offset the impacts, and unfair in distribution with regard to level and scope (Jørgensen, 2019; Jørgensen et al. 2020). An inherent problem of the instrument is thus the perception that developers collect unreasonably large profits, while unreasonable burdens are imposed on the neighbours. Moreover, the burdens are not only perceived as financial, they are also seen as non-financial and relating to conditions such as a sense of not feeling at home and as the cause of stress symptoms, sleep disruption and other disturbances.

Thirdly, the calculation of the compensation lacks transparency. For instance, the assessment of the visual impact of a wind farm will always be subjective. Furthermore, experience shows that affected property owners have difficulty comprehending that it is not the disturbance as such that is compensated; it is the impact of wind turbines or solar parks on property values (Olsen and Anker, 2014; Energy Agency, 2019a). Accordingly, when the property value is low, the assessed compensation becomes similarly low. In some cases, a dwelling is in such a bad condition that there is no loss of property value, while neighbours living further away from the same site, with less disturbances but in dwellings in a better state, are granted compensation. ${ }^{24}$ This may lead to perceptions that the scheme is unfair, not only in comparison with the perceived financial benefits to the developer, but also in comparison with other neighbours (Jørgensen, 2019). Consequently, neighbours of a renewable energy facility who do not receive their expected compensation will feel they have been treated unfairly, and may as a result be dissatisfied not only with the decision of the Valuation Authority, the developer and the renewable energy facility, but also with the local authorities and perhaps even with other neighbours.

In a number of cases, unfulfilled expectations have led to requests for the reopening of cases and litigation (Olsen and Anker, 2014); Olsen, 2015,2016 ). Such requests to reopen cases (that is the decision made by the Valuation Authority) have been submitted in approximately 20 per cent of cases. Several cases have also been reviewed by the Danish courts, including two by the Supreme Court, in 2017 and 2018. ${ }^{25} \mathrm{Al}-$ though the courts have upheld the level of compensation granted by the Valuation Authority in most cases, case law has not been entirely concurrent. To some extent, the Supreme Court has rectified this problem. It held in both judgements that in view of the expertise and function of the Valuation Authority, a court can overturn the decision of the Valuation Authority only if solid grounds prevail. As a result, it is not sufficient that the opinion of an independent surveyor differs from the decision of the Valuation Authority. The case law of the Supreme Court may have reduced the chances of overriding the decisions of the Valuation Authority, and as a result decreased the number of court cases, but it has not reduced the lack of transparency in the actual application of the legal instruments.
A fourth observation is that changing the time of the assessment of the compensation scheme - and the concurrent introduction of the acquisition option - may actually lead to an increase in requests to reopen cases and, accordingly, also litigation. Under the current scheme, the price determination is just an estimate based on a desktop survey of the Central Register of Buildings and Dwellings and the housing market prices of that particular area, combined with a brief inspection of the property. In most cases, this assessment would be nowhere near adequate when it comes to a conveyance of the ownership. In addition, contrary to the current situation, it is likely that developers will also be forced to litigate the price of a dwelling if the acquisition option is activated. The latest amendments would thus add to the lack of transparency.

Fifthly, depending on the response to instrument among neighbours eligible under the acquisition option, it may also affect the geographical distribution of renewable energy facilities even further, and consequently increase the uneven allocation placing such facilities primarily in the areas with the lowest house prices (Concito, 2018). This may increase the perception of unfairness among citizens living in those areas. From a developer point of view, this new measure may also be counterproductive to an aim of fewer, but bigger projects. It may obstruct the voluntary buying up of neighbouring properties carried out by some developers during the initial planning process, given that the acquisition option constitutes a future right for the closest neighbours that may affect their willingness to give up their homes at this early stage in the process.

A sixth observation is that the 'compensation' provided by the bonus scheme may become so insignificant that it will be perceived as unimportant and, consequently, have limited effect. The bonus scheme and the green fund are separate from the above mentioned schemes, primarily because the compensation provided is not connected to ownership. Moreover, the compensation is more indirect, given that neither of the schemes compensate any specific monetary loss of value. Over a period of time, the green fund may ex post increase local acceptance of specific renewable energy projects, provided it profits the community affected. However, the instrument may have less influence on local opinion in the crucial initial planning phases.

In conclusion, the need for financial measures to promote local acceptance is acknowledged, while it is disputable whether the Renewable Energy Act provides the most suitable legal framework. A more transparent and less complex framework to consider is an approach similar to one used when locating new overhead power lines and highvoltage pylons. As a starting point, the compensation would thus in most cases be based on standardised principles and rates, and there would only be a need to determine additional compensation in exceptional cases, while cases of conflict would involve the use of (compulsory) acquisition measures. Another, but considerably more positive mindset or approach than the existing schemes, would be the introduction of the concept a 'local tariff', that would bring cheaper renewable electricity to local residents by offering reduced tariffs. With a well-thought-out design, such an initiative could even bring about a positive vibe to dwellings in the vicinity of renewable energy facilities, comparable to the strong focus on a house's energy label when purchasing one, thus providing dwellings in renewable energy-intensive areas with a higher market value.

\footnotetext{
24 See, for example, Decision of the Valuation Authority concerning Engholmvej 5, 6950 Ringkøbing, Case 09/618.

25 UfR 2017.3354, Ejstrup Case and UfR 2018.3205, Nørhede-Hjortmose Case.
} 


\subsection{THOUGHTS ON LOCAL OPPOSITION AND OFFSHORE RENEWABLE ENERGY}

The instruments laid down in the Renewable Energy Act are aimed at onshore facilities, but do in some cases include near-shore projects, including so-called 'open door' projects. ${ }^{26}$ This may seem logical from a general point of view, as offshore infrastructure, such as an offshore wind farm, which has been subject to a site-specific tender, in some cases is neither visible nor audible from shore. However, this view ignores the fact that not all offshore facilities are 'invisible' and that all large offshore installations come with large onshore infrastructures. Given that an increased focus on offshore developments is inherent in the next steps towards climate neutrality, there is a need to consider the design of potential regulatory measures that aim at improving the relationship between offshore project developers and the affected onshore communities and landowners.

A major shortcoming of the current legal framework - aside from the negative outlook, lack of transparency and the difficulties of offsetting perceptions of unfair distribution - is the lack of flexibility that follows from static legal provisions that do not consider individual circumstances, such as positive attitudes, prior experience with wind energy, confidence in local authorities or high involvement in decision-making processes. In consequence, there is in most cases a lack of impetus to do more than what is required by law.

However, would it be possible to think of community acceptance mechanisms as dynamic instruments rather than static standards? Is it possible to design regulatory measures within a legal framework, but still with an inherent flexibility that can be applied in the light of variations among the specific places, people and communities? While the more traditional compensatory approach may be difficult to discard entirely in relation to land-based facilities, it may be possible to implement with regard to offshore renewables that have so far been 'under the radar'.

One approach could be to revisit the design of the offshore tender process, and the traditional basis that the only criterion in selecting the winner is the price, and turn towards strategies that incorporate community acceptance into the tender criteria. In the design of any tender system, focus should be on a careful blend of financial and technical criteria, and on project milestones. However, besides a number of financial and technical criteria, it is possible to include other limitations or non-financial criteria, which may enhance renewable energy development.

A potential limitation as part of the tender criteria could come in the shape of a mandatory CSR strategy for community acceptance that would not only address this, but also require the implementation of initiatives designed to improve the relationship with the specific local community, thus complementing business activities with socially responsible actions that acknowledge and support local communities.

\section{CONCLUSION AND IMPLICATIONS FOR THE GREEN TRANSITION}

The Danish Renewable Energy Act has for more than a decade applied various financial measures to promote local acceptance. Nevertheless, this approach is not yet fully developed and there is a need for further understanding of how different measures work, also in relation to more recently introduced renewables within the local acceptance framework of the Renewable Energy Act, such as solar power. However, concurrently there is also an opportunity for lawmakers to consider instruments that are more transparent, that provide a more positive outlook or the option to develop a more dynamic and flexible approach that would include measures tailored to meet the distinct needs of a community or landowner.

While debates on local acceptance are not new to the energy sector, local opposition continues to grow. Generally, the opposition has become more organized and it has adopted a more professional approach. Consequently, the issue must be urgently addressed if policies are to be implemented successfully and targets met. This will require a rethinking of existing measures and perhaps even a new approach. Meanwhile, renewable energy providers are developing even larger projects whose impact on land- and seascapes are only increasing.

\section{REFERENCES}

Anker, H. T., \& Olsen, B. E. (2019). Blæst på havet: om beslutningsprocesser for havvindmøller i Danmark in Darpö, J, Forsberg, M, Pettersson, M and Zetterberg, C (Eds.), in Miljörätten och den förhandlingsovilliga naturen: Vänbok till Gabriel Michanek, Iustus förlag, 13-34.

Concito, 2018. Lokal accept og udvikling af vindmølleprojekter. Opsamling på Wind2050projektet. https://concito.dk/files/dokumenter/artikler/lokal_accept_og_udvikling_af vindmoelleprojekter_maj2018.pdf (accessed 22 December 2020).

Cowi, 2016. Analyse af vindmøllers påvirkning på priser på beboelsesejendomme, marts. Energistyrelsen, https://ens.dk/sites/ens.dk/files/Vindenergi/vindmoeller_paavirkning_priser_beboelsesejendomme.pdf (accessed 22 January 2020).

Devine-Wright, P. (2005). Beyond NIMBYism: Towards an Integrated Framework for Understanding Public Perceptions of Wind Energy, in Wind Energy: An International Journal for Progress and Applications in Wind Power Conversion Technology, 8(2), 125-139. https:// doi.org/10.1002/we.124.

Dröes, M. I., \& Koster, H. R. (2016). Renewable Energy and Negative Externalities: The Effect of Wind Turbines on House Prices. Journal of Urban Economics, 96, 121-141. https:// doi.org/10.1016/j.jue.2016.09.001.

Eltham, C., Harrison, G.P., and Allan, S J. (2008). Change in Public Attitudes Towards a Cornish Wind Farm: Implications for Planning. Energy Policy, 36(1), 23-33. https://doi. org/10.1016/j.enpol.2007.09.010.

Energy Agency, 2019a. Notat om værditabsordningen. https:/ens.dk/sites/ens.dk/files/Vindenergi/notat_om_vaerditabsordningen.pdf (accessed 22 December 2020).

Energy Agency, 2019b. Notat om salgsoptionen. https://ens.dk/sites/ens.dk/files/Vindenergi/ notat_om_salgsoptionsordning.pdf (accessed 22 December 2020).

Energy Agency, 2019c. Notat om VE-Bonusordningen. https:/ens.dk/sites/ens.dk/files/Vindenergi/notat_om_ve-bonus.pdf (accessed 22 December 2020). 
Energy Agency, 2019d. Notat om Grøn Pulje. https://ens.dk/sites/ens.dk/files/Vindenergi/ notat_om_groen_pulje.pdf (accessed 22 December 2020).

Hoen, B., Brown, J. P., Jackson, T., Thayer, M. A., Wiser, R., \& Cappers, P. (2013). Spatial Hedonic Analysis of the Effects of US Wind Energy Facilities on Surrounding Property Values. Ernest Orlando Lawrence Berkeley National Laboratory, https://emp.lbl.gov/ sites/all/files/lbnl-6362e.pdf (accessed 22 December 2020).

Horner, B., Jeffery, R. D., \& Krogh, C. M. (2011). Literature Reviews on Wind Turbines and Health: Are They Enough?. Bulletin of Science, Technology \& Society, 31(5), 399-413. https://doi.org/10.1177/0270467611421849.

Jensen, C. U., Panduro, T. E., \& Lundhede, T. H. (2014). The Vindication of Don Quixote: The Impact of Noise and Visual Pollution from Wind Turbines. Land Economics, 90(4), 668-682. https://doi.org/10.3368/le.90.4.668.

Jensen, C. U., Panduro, T. E., Lundhede, T. H., Nielsen, A. S. E., Dalsgaard, M., \& Thorsen, B. J. (2018). The Impact of On-shore and Off-shore Wind Turbine Farms on Property Prices. Energy Policy, 116, 50-59. https://doi.org/10.1016/j.enpol.2018.01.046.

Johansen, K., \& Emborg, J. (2018). Wind Farm Acceptance for Sale? Evidence from the Danish Wind Farm Co-ownership Scheme. Energy Policy, 117, 413-422. https://doi. org/10.1016/j.enpol.2018.01.038.

Jones, C. R., \& Eiser, J. R. (2010). Understanding 'Local' Opposition to Wind Development in The UK: How Big Is a Backyard?. Energy policy, 38(6), 3106-3117. https://doi. org/10.1016/j.enpol.2010.01.051

Jørgensen, M. L. (2019). Compensation Mechanisms and Local Acceptance of Wind Energy Projects: A Qualitative Case Study (Doctoral dissertation, Department of Food and Resource Economics, Faculty of Science, University of Copenhagen).

Jørgensen, M. L., Anker, H. T., \& Lassen, J. (2020). Distributive Fairness and Local Acceptance of Wind Turbines: The Role of Compensation Schemes. Energy Policy, 138, 111294. https://doi.org/10.1016/i.enpol.2020.111294.

Mortensen, B. O. G. (2011). Er en vindmølle fast ejendom i VE-lovens forstand?. Ugeskrift for Retsvaesen (u FR), 2008(163).

Nolon, S. F. (2010). Negotiating the Wind: A Framework to Engage Citizens in Siting Wind Turbines. Cardozo J. Conflict Resolution, 12, 327. https://cardozojcr.com/vol12no2/327-372.pdf (accessed 22 December 2020).

Olsen, B. E. (2010). Wind Energy and Local Acceptance: How To Get Beyond The Nimby Effect. European Energy \& Environmental. Law Review, 19, 239.
Olsen, B. E., \& Anker, H. T. (2014). Local Acceptance and The Legal Framework - The Danish Wind Energy case, in: L. Squintani and H. Vedder with M. Reese and B. Vanheusden (eds), Sustainable Energy United in Diversity-Challenges and Approaches in Energy Transition in the European Union, Forum Series, 1, 137-56. http://www.enace.es/Web/es/pdfs/ Sustainable_Energy_United_in_Diversity.pdf (accessed 22 December 2020).

Olsen, B. E. (2014). 10. Regulatory Financial Obligations for Promoting Local Acceptance of Renewable Energy Projects, in: Peeters, M. and Schomerus, T. (Eds.), Renewable Energy Law in the EU: Legal Perspectives on Bottom-up Approaches, Edward Elgar Publishing, 189-209.

Olsen, B. E. (2016). Renewable Energy: Public Acceptance and Citizens' Financial Participation, in: Farber, D.A. and Peeters, M. (Eds.), Elgar Encyclopedia of Environmental Law (pp. 476-486). Edward Elgar Publishing Limited.

Sunak, Y., \& Madlener, R. (2016). The Impact of Wind Farm Visibility on Property Values: A Spatial Difference-in-Differences Analysis. Energy Economics, 55, 79-91. https://doi. org/10.1016/j.eneco.2015.12.025.

Van der Horst, D. (2007). NIMBY Or Not? Exploring the Relevance of Location and The Politics of Voiced Opinions in Renewable Energy Siting Controversies. Energy policy, 35(5), 2705-2714. https://doi.org/10.1016/j.enpol.2006.12.012.

Vyn, R. J., \& McCullough, R. M. (2014). The Effects of Wind Turbines on Property Values in Ontario: Does Public Perception Match Empirical Evidence?. Canadian Journal of Agricultural Economics/Revue canadienne d'agroeconomie, 62(3), 365-392. https://doi-org. ez.statsbiblioteket.dk:120 48/10.1111/cjag.12030.

Vyn, R. J. (2018). Property Value Impacts of Wind Turbines and the Influence of Attitudes toward Wind Energy. Land Economics, 94(4), 496-516. https://doi. org/10.3368/ le.94.4.496.

Wolsink, M. (2000). Wind Power and the NIMBY-myth: Institutional Capacity and the Limited Significance of Public Support. Renewable energy, 21(1), 49-64. https://doi. org/10.1016/S0960-1481(99)00130-5.

Wolsink, M. (2012). Undesired Reinforcement of Harmful 'Self-Evident Truths' Concerning the Implementation of Wind Power. Energy Policy, 48, 83-87. https://doi. org/10.1016/j. enpol.2012.06.010.

Wüstenhagen, R., Wolsink, M., \& Bürer, M. J. (2007). Social Acceptance of Renewable Energy Innovation: An Introduction to the Concept. Energy policy, 35(5), 2683-2691. https:// doi.org/10.1016/j.enpol.2006.12.001. 